Ключевые слова: специальные знания, процессуальные и непроцессуальные, непосредственные и опосредованные, основные и факультативные формы использования специальных знаний, назначение судебных экспертиз, участие специалиста в следственных действиях, справочно-консультационная форма, учеты, ревизии.

\title{
FORMS OF SPECIAL KNOWLEDGE USE
}

\section{Spitsyna H. O., Bidniak H. S.}

The article deals with problematic issues regarding the forms of special knowledge use while crime investigation, legislative acts are analyzed. Based on the opinion analysis of criminalistic scientists, forms of special knowledge use divided according to different criteria into procedural and non-procedural, direct and indirect, basic and optional are detailed. The most commonly used forms are indicated, among them: appointment of forensic examinations, involvement of specialist for performing investigative actions, consulting and reference, auditing and monitoring of records, the presence of an investigator during an examination, expert questioning. Legislation changes concerning of examination by a Forensic science institution (expert) only according to the investigating judge decision or court made on the petition of one of the parties to criminal proceedings are analyzed. Positive reform aspects, as well as the argument about the loss of procedural independence of the investigator while decision making under such circumstances were highlighted; it was suggested to review the above changes. Taking into account legislation changes, the role of the specialist during the search relatively of mandatory fixation of this act by means of audio and video recording is indicated. Problem issues existing in the units of criminalistic support during investigative actions are outlined and the mechanism of their solution is proposed. Attention is focused on the use of automated records and prospects for their development.

Keywords: special knowledge, procedural and non-procedural, direct and indirect, basic and optional forms of special knowledge use, appointment of forensic examinations, participation of an expert in investigative actions, reference and consulting form, records, revisions.

DOI: https://doi.org/10.32353/khrife.2018.27

УДК 343.98

C. M. Попович, головний науковий співробітник Харківського НДІСЕ, доктор юридичних наук, професор

E-mail: hniise@gov.ua

\section{ПРИНЦИПИ ОРГАНІЗАЦІї \\ ТА ФУНКЦІОНУВАННЯ АВТОМАТИЗОВАНИХ СИСТЕМ У СУДОВО-ЕКСПЕРТНІЙ ДІЯЛЬНОСТІ}

Досліджено проблеми, пов'язані із розумінням, класифікацією та реалізацією принципів організації й функціонування автоматизованих систем у судово-експертній діяльності. Також наведено авторське визначення законності в судово-експертній діяльності, під якою розуміється складне сочіально-правове явище, основним критерієм якого є категорія правомір-

(C) Попович С. М., 2018 
ності, щзо складається з сукупності суб 'єктивних прав, відображених і закріплених у чинному законодавстві, які склалися в результаті об'єктивного суспільного розвитку.

Ключові слова: принщипи роботи, інформаційні системи, судово-експертні дослідження, інформачійне забезпечення, експертні системи.

Системна обробка інформації залишається важливим фактором підвищення ефективності судово-експертної діяльності. Вирішальну роль у використанні інформації відіграють способи ії реєстрації, оброблення, накопичення й передачі, систематизоване збереження інформації та видача в потрібній формі. Одним із основних показників інформаційної системи $€$ iiï технічна оснащеність, під якою розуміється комплекс технічних засобів, призначених для роботи інформаційної системи, а також відповідна документація на ці засоби та технологічні процеси.

Виходячи із сутності нашої роботи, розглянемо системи, що можуть використовуватися в діяльності судово-експертних установ. Залежно від призначення бази даних інформації, порядку пошуку інформаційні системи в експертній діяльності диференціюються на такі види: документальні та фактографічні ${ }^{1}$.

Документальні інформаційні системи містять масив даних, що складається з документів, які не піддавалися формалізації, тобто виконані відповідним способом. Такими документами можуть бути законодавчі акти, висновки експертних досліджень, аналітичні довідки й інші документи. Отже, документальними інформаційними системами $є$ такі, що виконують пошук документів у зв'язку із запитом, із подальшою видачею користувачу цих документів (їх копій) чи їх облікових номерів. Підготовка до одержання інформації в системі й подальше ії оброблення проводяться безпосередньо користувачем.

Фактографічні інформаційні системи містять масив даних (факти, ознаки), поданих у формалізованому вигляді. Для таких систем створені спеціальні класифікатори, які відповідну мову документів перекладають на штучну (формалізовану). У фактографічних інформаційних системах відомості користувач одержує безпосередньо на запит. Тому в таких системах проводиться пошук не конкретного документа, а відомостей, що містяться в первинних документах за запитом користувача. Отже, відмінність фактографічних інформаційних систем від документальних полягає в тому, що фактографічні системи видають не заздалегідь весь уведений документ, а оброблену часткову інформацію з конкретного документа ${ }^{2}$.

Установи судових експертиз у своїй діяльності використовують в основному фактографічні інформаційні системи. Під фактографічною інформа-

1 Захарова I. В., Філіпова Л. Я. Основи інформаційно-аналітичної діяльності : навч. посіб. для студ. вищ. навч. закл. Київ : Центр учб. літ., 2013. С. 33.

2 Пілюков В. О. Використання інформаційних систем в експертних підрозділах МВС України : дис. ... канд. юрид. наук : 12.00.09. Київ, 2009. С. 44. 
цією слід розуміти відомості не лише фактичного характеру, а й теоретичного, оціночного характеру, тобто вона має включати факти, концепції, усе те, що може бути об'єктом вилучення з тексту, описання певною інформаційною мовою, що зберігаються в тій чи іншій інформаційній системі ${ }^{1}$, наприклад, дактилоскопічні системи обліку. У цих системах особа описується комплексом ознак анкетного характеру (на дактилокарті, крім відбитків десяти пальців рук, указуються прізвище, ім'я, по батькові, рік і місяць народження особи, підстави для дактилоскопіювання тощо), а також за відбитками пальців рук виводяться основна і додаткова формули, що являють собою ряд цифр чисельника й знаменника (своєрідний код особи). За таким кодом, зокрема за додатковою формулою, можна визначити тип і вид папілярного візерунка будь-якого відбитка пальця руки конкретної особи. Прямий доступ до інформації, збереженої у фактографічних системах, сприяє ефективному проведенню досліджень об'єктів (речових доказів) за картотеками та слідотеками. Фактографічні інформаційні системи, як і документальні, нині автоматизуються на базі різних марок і типів ЕОМ².

Кожна інформаційна система залежно від мети створення може бути побудована за певними принициами.

Найголовніший принцип діяльності будь-якої організації чи системи - це принцип законності. Законність (ст. 8 п. 1 ч. 3 ст. 129 Конституції) - це основна засада, яка $є$ універсальною та знаходить свій вияв у всіх нормах процесуального права, характеризує всі сторони судочинства. У правовій державі, якою проголосила себе Україна, діє принцип верховенства права. Конституція України має найвищу юридичну силу. Закони, нормативноправові акти приймаються на іії основі та відповідають їй. Норми Конституції України є нормами прямої дії. Принцип законності полягає в єдиному порядку провадження в справі відповідної юрисдикції, виконанні процесуальної форми та передбаченої процедури застосування законуз

Законність, на думку В. Д. Ткаченка, можна розглядати в аспекті необхідності (вимоги, обов'язку) виконувати норми права. Це свідчить про іiі органічний, нерозривний зв'язок із правом як системою норм і принципів. Суспільство, а також держава, яка визнає й захищає правові норми, вимагають неухильного й суворого їх дотримання та виконання всіма суб'єктами суспільних відносин. Такі вимоги норми права (закону) склалися ще тисячоліття тому та лише сьогодні дістали в юридичній науці назву законності як прояву загальної обов'язковості права. Однак вимоги виконання права для характеристики законності недостатньо. Необхідно забезпечити реальний вплив права на поведінку людей. У цьому аспекті законність - це додержання й виконання норм права (законів) органами держави, посадовими особами, громадянами та їх соціальними організаціями, тобто здійснення ними правомірних дій. У разі, коли норма права (закон) приписує учасникам

\footnotetext{
1 Захарова I. В., Філіпова Л. Я. Зазнач. твір. С. 34.

Пілюков В. О. Зазнач. твір. С. 45.

3 Чернишова Н. В. Судова влада в Україні : навч. посіб. Київ : Центр учб. літ., 2011. C. 8.
} 
суспільних відносин здійснювати певні дії, законність виявлятиметься в точному виконанні норм права (законів); якщо норма права (закон) забороняє здійснювати певні дії, законність означатиме утримання від здійснення таких дій; якщо закон (норма права) надає суб'єктам суспільних відносин право здійснювати на свій розсуд певні дії, законність диктуватиме неможливість виходу за ії межі. Законність завжди означає відповідність поведінки (діяльності) суб’єктів суспільних відносин нормі права (закону)ํ.

О. Ф. Скакун термін «законність» інтерпретує як комплексне поняття, що охоплює всі сторони існування права - від його ролі у створенні закону до реалізації його норм у юридичній практиці. Законність відображає правовий характер організації суспільно-політичного життя, органічність зв'язків права й влади, права й держави, права й суспільства. Вимоги законності рівною мірою стосуються вищих органів державної влади, інших державних органів, що приймають у рамках своєї компетенції підзаконні акти (сфера правотворчості), безпосередніх виконавців законів - посадових осіб, а також громадських організацій, комерційних корпорацій, громадян (сфера правореалізації). Законність характеризується єдністю двох ознак: зовнішньої (формальної) - обов’ язком виконувати приписи законів і підзаконних актів державними органами, посадовими особами, громадянами та іншими об’єднаннями; внутрішньої (сутнісної) - наявністю науково обгрунтованих і відповідаючих праву законів, якістю законів ${ }^{2}$.

Вивчаючи сутність згаданого принципу, О. М. Бандурка підкреслював, що принцип законності полягає в тому, що посадові особи зобов'язані виконувати вимоги законодавства в точній відповідності до їх змісту. Будучи принципом і методом суспільних відносин, режимом соціального життя, законність $є$ складовою частиною механізму регулювання суспільних відносин, є обов'язковою умовою правопорядку, державної й громадської дисципліни, важливим елементом демократії та культури ${ }^{3}$.

Забезпечення принципу законності при здійсненні судово-експертної діяльності можливе при реалізації багатьох вимог. До найбільш значущих можна віднести: 1) суворе дотримання вимог Конституції України, законів і підзаконних нормативно-правових актів; 2) високий рівень загальної та професіональної правосвідомості працівників судово-експертних установ; 3) постійне вдосконалення правових і морально-етичних основ діяльності співробітників судово-експертною установою; 4) забезпечення конфіденційності відомостей, що стали відомі судовому експерту під час вивчення відповідних матеріалів; 5) зміцнення престижу професії тощо.

Отже, законність у судово-експертній діяльності являє собою складне сочіально-правове явище, основним критерієм якого є категорія правомір-

1 Загальна теорія держави і права / за ред. М. В. Івіна, В. Д. Ткаченка, О. В. Петришина. Харків : Право, 2002. С. 385.

2 Скакун О. Ф. Теория государства и права : учебник. Харьков : Консум, 2000. C. 483.

Бандурка О. М. Оперативно-розшукова діяльність : підручник. Харків : ХНУВС, 2002. Ч. 1. С. 88. 
ності, щуо складається з сукупності суб'єктивних прав, відображених $i$ закріплених у чинному законодавстві, які склалися в результаті об 'єктивного суспільного розвитку.

Принципи відбору інформації необхідно реалізовувати для того, щоб відібрані дані були необхідними та в той самий час не були надмірними й тим самим не створювали труднощі в користуванні інформацією. Тобто інформація повинна бути достовірною, актуальною та повною. Інформація повинна виходити з достовірних джерел, оброблятися за допомогою надійних методів і не спотворюватися в процесі її передачі. Відомості, що включаються в інформаційну систему, повинні бути актуальними, тобто відображати сучасний стан науки й техніки в галузі судової експертизи. Повнота інформації забезпечується охопленням усіх даних, що необхідні. Неприпустимим $є$ вибірковість відібрання даних, що може призвести до помилкових висновків ${ }^{1}$.

Інформаційне забезпечення експертної діяльності обов'язково включає принцип використання апаратних і програмних модулів. Під апаратним модулем розуміється уніфікований функціональний вузол, виконаний у вигляді самостійного виробу. Модулем програмного забезпечення можна вважати уніфікований програмний елемент, що виконує певну функцію в загальному програмному забезпеченні. Дотримання принципу використання програмних і апаратних модулів дозволить: забезпечити сумісність обчислювальної техніки і програмного забезпечення на різних рівнях судово-експертної роботи; підвищити ефективність функціонування інформаційних систем; прискорити побудову уніфікованих інформаційних моделей.

Інформаційна система завжди будується із урахуванням принципу можливості ї̈ поетапного створення. Це означає, що при проектуванні системи необхідно передбачити можливість постійного збільшення числа об'єктів автоматизації, розширення складу користувачів системи, невпинного зростання кількості розв'язуваних завдань тощо.

Система інформаційного забезпечення судово-експертної діяльності повинна здійснюватися за принципом простоти та гнучкості з погляду специфічних вимог конкретного застосування. Сьогодення вимагає від судомо-експертної практики всебічного використання сучасних досягнень науки й техніки. Тому інформаційна система має бути пристосована до цього та мати певні, заздалегідь передбачені резерви. Також система не повинна викликати фізичних і психологічних навантажень у іiі користувача. Система інформаційного забезпечення має здійснюватися за принципом гнучкості, тобто легко адаптуватися до зростаючих і мінливих потреб, до розширення інформаційних можливостей, включенню в неї нових даних.

Один із найважливіших - це принцип прийнятності системи для користувача діалогу «людина - машина». При роботі людини з обчислювальною машиною виникають психологічні бар'єри. Практика побудови автоматизованих систем у цілому вимагає використання психологічних знань. До

1 Автоматизация судебной экспертизы, ее программное обеспечение. Судебный эксперт - психолог. URL: http://www.sud-expert.net/index/0-36. 
останнього часу в центрі уваги психологів, які орієнтуються на цю проблему, був оператор. Нині все більшого значення набувають дослідження діяльності користувачів ЕОМ (експертів-криміналістів, наукових і управлінських працівників та ін. $)^{1}$.

Принции розподілу інформаційного забезпечення зумовлений необхідністю розв'язання різноманітних експертних завдань, тому інформаційне забезпечення експертної діяльності йде шляхом створення відносно автономних підсистем, що визначаються видом вирішуваних завдань. Такі підсистеми повинні давати експертам можливість легко орієнтуватися в їх структурі та інформаційних масивах ${ }^{2}$.

Методологічні принциии формування автоматизованих інформаційних систем повинні відповідати двом головним вимогам: а) усебічно відображати дійсність; б) оптимально перетворювати дійсність в інтересах експерта на основі формування цілісної системи знань про всю сукупність методик досліджень, властивості об'єктів, тенденції розвитку в їх оптимальному вираженні з урахуванням конкретних умов.

Велике значення має принцип новизни завдань. Суть принципу полягає в зміні традиційно сформованих методів і прийомів інформаційного забезпечення відповідно до нових можливостей, що дають ЕОМ. Це означає, що при аналізі роботи інформаційної системи виявляються втрати в ії організації (нераціональне завантаження устаткування, простої тощо). За результатами аналізу складається список завдань, що на застарілих ЕОМ вирішуються неповно, але які можна вирішити за допомогою сучасних електронно-обчислювальних комплексів ${ }^{3}$.

Приничип структурної організації інформаційного забезпечення має на меті розподіл інформації з урахуванням її класифікації за класами, видами, підвидами тощо. Оптимально діюча система повинна конструюватися таким чином, щоб вона допомагала правильно побудувати запит шляхом його уточнення та конкретизації. Таку функцію може виконати інформаційна система, побудована за діалоговим принципом. Інформаційні системи повинні розроблятися таким чином, щоб вони легко інтегрувалися в єдину систему. Зовні різнорідні системи інформаційного забезпечення будуються у вигляді єдиної системи, об’єднаної, наприклад, єдиним об'єктом. Так, може бути створена єдина система про барвники всіх видів, яка може бути рівною мірою використовуватися при дослідженні як матеріалів, речовин, виробів, так і при технічному дослідженні документів ${ }^{4}$.

Сучасна інформаційна система повинна враховувати принции системного niдxодy. Системний підхід - напрям методології спеціально-наукового пізнання й соціальної практики, в основі якого лежить дослідження об'єктів

\footnotetext{
${ }^{1}$ Вертузаєв М. С., Коваленко М. М., Черевик В. М. Експертні системи в діяльності органів внутрішніх справ : метод. розробка. Київ : Нац. акад. внутр. справ України, 1997. C. 17-21.

Автоматизация судебной экспертизы, ее программное обеспечение.

Пілюков В. О. Зазнач. твір. С. 53.

4 Автоматизация судебной экспертизы, ее программное обеспечение.
} 
як систем. Системний підхід сприяє адекватній постановці проблем у конкретних науках і виробленні ефективної стратегії їх вивчення. Методологія, специфіка системного підходу визначається тим, що він орієнтує дослідження на розкриття цілісності об'єкта й механізмів, що забезпечують $і 1$, на виявлення багатообразних типів зв'язків складного об'єкта й зведення їх у єдину теоретичну картину ${ }^{1}$. Створювати інформаційну систему необхідно на підставі системного аналізу й об'єкта, й системи керування об'єктом. Зокрема, необхідно встановити мету, а також критерії функціонування об'єкта керування, провести їх структуризацію, що відкриває весь комплекс із проблем інформаційної достатності, яку необхідно вирішувати, щоб створювана система щонайкраще відповідала заданим цілям і встановленим критеріям. Цей комплекс поєднує в собі технічну, економічну та організаційну потреби. Застосування принципу системного підходу є важливим, тому що дозволяє використовувати математичний апарат і обчислювальну техніку у створенні інформаційної системи в судово-експертній діяльності.

Принции сполучення підготовки первинних і машинних документів суттєво зменшує можливість суб'єктивних помилок. Цього можна досягти такими шляхами: об'єднання первинного й машинного документа в єдиний документ; використання пристроїв, що одночасно готують первинний документ і його машинну копію (флексорайтери); безпосереднє підключення до ЕОМ пристроїв, на яких готуються первинні документи (принтери). Крім зменшення можливості помилок, дотримання цього принципу ліквідує необхідність у додатковій праці з переносу первинних документів на машинні носії.

Принцип погодженості пропускних можливостей окремих частин системи передбачає узгодженість пропускних можливостей окремих пристроїв (номінальну швидкість їх роботи) і їх надійність. Немає необхідності збільшувати швидкість виконання операцій на ЕОМ, якщо при вирішенні конкретних завдань вузьким місцем у системі $є$ швидкість вводу чи обміну інформацією між зовнішньою пам'яттю та центральним процесором.

Принцип захищеності банків даних особливо актуальний при проведенні судових експертиз, тому що експерти займаються специфічною діяльністю, а така діяльність повинна бути захищена від несанкціонованих дій сторонніх осіб. Сутність цього принципу полягає в такому: у створюваних інформаційних системах міститься інформація, доступ до якої дозволений визначеному колу осіб, тому інформаційна система повинна мати спеціальний пристрій захисту від втручання в систему сторонніх осіб. 3 цієї причини користувач має свій «ключ» (код, шифр), за допомогою якого він отримує доступ до свого інформаційного масиву.

Способи захисту інформації також повинні враховувати ситуації випадкового знищення, несанкціонованого тиражування, виключати роботу 3 системою некомпетентного користувача, що намагається на свій розсуд

\footnotetext{
1 Всі слова. URL: http://vseslova.com.ua/word/Системний_підхід-97623u.
} 
унести в неї виправлення або доповнення. Ефективні системи мають великі обсяги інформації, що робить необхідним їх автоматизацію ${ }^{1}$.

Принциип використання професійної мови дозволяє здійснити зв'язок експерта (користувача) з інформаційною системою на професійній мові, відтворити вхідну і вихідну інформацію у формі, зручній для розуміння користувача, проводити корегування процесу вирішення завдання без порушення методик дослідження з використанням єдиної термінології².

Викладені принципи організації та функціонування автоматизованих систем можуть і повинні використовуватися при створенні інформаційних систем судово-експертної діяльності.

\section{ПРИНЦИПЫ ОРГАНИЗАЦИИ И ФУНКЦИОНИРОВАНИЯ АВТОМАТИЗИРОВАННЫХ СИСТЕМ В СУДЕБНО-ЭКСПЕРТНОЙ ДЕЯТЕЛЬНОСТИ}

\section{Попович $\mathrm{E} . \mathrm{H}$.}

Исследованы проблемы, связанные с пониманием, классификацией и реализацией принципов организации и функционирования автоматизированных систем в судебно-экспертной деятельности. За основу классификации приняты системы, которые могут использоваться в деятельности судебно-экспертных учреждений. В зависимости от назначения информационные системы дифференцируются на следуюшие виды: документальные и фактографические. Учреждения судебных экспертиз в своей деятельности используют, в основном, фактографические информационные системы. Каждая информационная система, в зависимости от цели создания, может быть построена по определенным принципам. Нами приведен детальный анализ таких первооснов деятельности автоматизированной системы, а именно: принции законности; принциип отбора информации; принцип использования аппаратных и программных модулей; принции возможности поэтапного создания информационной системы; принции простоты и гибкости с точки зрения специфических требований конкретного применения информационной системь; приниип приемлемости системь для пользователя диалога «человек-машина»; принцип распределения информационного обеспечения; приниип новизны задач; принциип структурной организации; принцฺип системного подхода; принции сочетания подготовки первичных и машинных документов; принцип согласованности пропускных возможностей отдельных частей системы; принцип защиищенности банков данных; принщип использования профессионального языка и торское определение законности в судебно-экспертной деятельности, под которой понимается сложное социально-правовое явление, основным критерием которого является категория правомерности, состоящая из совокупности субъективных прав, отраженных и закрепленных в действующем законодательстве, которые сложились в результате объективного общественного развития.

Ключевые слова: принципы работы, информационные системы, судебно-экспертные исследования, информационное обеспечение, экспертные системы.

\footnotetext{
1 Автоматизация судебной экспертизы, ее программное обеспечение.

2 Пілюков В. О. Зазнач. твір. С. 58-59.
} 


\section{PRINCIPLES OF ORGANIZATION AND FUNCTIONING OF AUTOMATED SYSTEMS IN FORENSIC EXPERT ACTIVITY}

\section{Popovich E. N.}

This article presents problems related to understanding, classification and implementation of the principles of organization and operation of automated systems in forensic expert activity. The basis of the classification is adoption of systems that can be used in activities of forensic science institutions. Depending on the destination, information systems differentiate into the following types: documentary and factographic. Forensic science institutions mainly use factographic information systems in their activities. Each information system, depending on the purpose of creation, can be constructed according to certain principles. We have provided a detailed analysis of such fundamental principles of automated system activity, namely: principle of legality; principle of information selection; principle of using hardware and software modules; principle of the possibility of step-bystep creating an information system; principle of simplicity and flexibility in terms of specific requirements of concrete information system application; principle of system acceptance for user of the "human - machine" dialogue; principle of distribution of information support; principle of task originality; principle of structural organization; principle of system approach; principle of combining the preparation of primary and machine documents; the principle of consistency of bandwidth of individual parts of a system; principle of data bank security; principle of using a professional language, etc. Author's definition of legality in forensic expert activity is presented that is understood as a complex social and legal phenomenon which main criterion is the legality category consisting of a set of subjective rights reflected and fixed in current legislation, formed as a result of objective social development.

Keywords: principles of work, information systems, forensic expert researches, informational support, expert systems.

DOI: https://doi.org/10.32353/khrife.2018.28

УДК 343.982 .323

B. B. Tonчій, директор Навчально-наукового інституту права Університету державної фіскальної служби України, доктор юридичних наук, професор, заслужений юрист України

E-mail: tv1959@ukr.n

\section{АКТУАЛЬНІСТЬ СУДОВОЇ МОЛЕКУЛЯРНО-ГЕНЕТИЧНОЇ ЕКСПЕРТИЗИ ТА ПРОБЛЕМНІ ПИТАННЯ ЩОДО ЇЇ ПРОВЕДЕННЯ}

Розглянуто особливості та сучасні можливості використання молекулярно-генетичних методів дослідження під час кримінального провадження. Проаналізовано проблеми проведення судової молекулярно-генетичної експертизи та визначено иляхи їх вирішення, а також перспективи використання ДНК-аналізу в Україні.

Ключові слова: ДНК-аналіз, молекулярно-генетична експертиза, ідентифікація, генотипоскопія, кримінальне провадження.

(C) Топчій В. В., 2018 